\title{
Concentration-dependent effects of rapamycin on proliferation, migration and apoptosis of endothelial cells in human venous malformation
}

\author{
YAMENG SI $^{1,2}$, HANCHEN CHU $^{3}$, WEIWEN ZHU $^{1}$, TAO XIAO $^{1}$, XIANG SHEN $^{1}$, \\ $\mathrm{YU} \mathrm{FU}^{1}$, RONGYAO XU ${ }^{1}$ and HONGBING JIANG ${ }^{1,4}$
}

\author{
${ }^{1}$ Jiangsu Key Laboratory of Oral Diseases, Nanjing Medical University, Nanjing, Jiangsu 210029; \\ ${ }^{2}$ Department of Oral and Maxillofacial Surgery, Xuzhou Central Hospital, Xuzhou, Jiangsu 221009; \\ ${ }^{3}$ College of Stomatology, Xuzhou Medical University, Xuzhou, Jiangsu 221004; ${ }^{4}$ Department of Oral and
}

Maxillofacial Surgery, Affiliated Stomatological Hospital of Nanjing Medical University, Nanjing, Jiangsu 210029, P.R. China

Received March 5, 2018; Accepted July 27, 2018

DOI: $10.3892 /$ etm.2018.6782

\begin{abstract}
Rapamycin has been reported to be immunosuppressive and anti-proliferative towards vascular endothelial and smooth muscle cells. The purpose of the present study was to investigate the effects of rapamycin on the biological behaviors of endothelial cells that have been separated from the deformed vein in human venous malformation (VM). Cellular morphology was observed using inverted microscopy. An MTT assay was performed to measure the cell viability at different concentrations of rapamycin and different time points. Cell apoptosis and migration were detected using a terminal deoxynucleotidyl-transferase-mediated dUTP nick end labeling assay and a wound-healing assay, respectively. At 48 and $72 \mathrm{~h}$, rapamycin inhibited proliferation of human VM endothelial cells, with the effects becoming more pronounced with increasing concentration. Only rapamycin at a concentration of $1,000 \mathrm{ng} / \mathrm{ml}$ had a significant effect at $24 \mathrm{~h}$ in repressing proliferation. At $48 \mathrm{~h}$, compared with the blank group, the majority of cells maintained a clear nuclear boundary and a regular shape following treatment with $1 \mathrm{ng} / \mathrm{ml}$ rapamycin; 10 and $100 \mathrm{ng} / \mathrm{ml}$ rapamycin caused desquamation and rounded shape; and 1,000 $\mathrm{ng} / \mathrm{ml}$ rapamycin caused even more marked desquamation, rounded shape and necrosis. Rapamycin at concentrations of 1, 10, 100 and 1,000 ng/ml reduced cell viability, increased the number of apoptotic cells and suppressed the migration capacity of human VM endothelial cells, and the effects became more pronounced with increasing concentration, when compared with the blank
\end{abstract}

Correspondence to: Dr Hongbing Jiang, Jiangsu Key Laboratory of Oral Diseases, Nanjing Medical University, 136 Hanzhong Road, Nanjing, Jiangsu 210029, P.R. China

E-mail: jhb@njmu.edu.cn

Key words: rapamycin, venous malformation, endothelial cells, cell viability, concentration-dependence group. These findings provide evidence that rapamycin induces apoptosis and inhibits proliferation and migration of human VM endothelial cells in a concentration-dependent manner.

\section{Introduction}

Venous malformations (VMs) consist of distorted and ectatic veins, which are enveloped sparsely by smooth muscle cells (SMCs) (1). VMs are low-flow vascular anomalies and will develop throughout life in the body without appropriate management $(2,3)$. VMs comprise $50-75 \%$ of vascular malformations (4). Almost $40 \%$ of VMs are located in the head and neck region, particularly in the oral cavity, airway tract and related muscles (5). According to Legiehn and Heran, $98 \%$ of VMs are sporadic and non-inherited, and inherited VMs are typically multifocal (6). It has been estimated that VM occurs at an incidence of 1-2 individuals per 10,000 births (7). VMs in the temporal muscle of the face commonly cause cosmetic deformity and migraine, and those located in the extremities often lead to the development of hypotrophy or hypertrophy, as well as muscle weakness (8). Treatment regimens include sclerotherapy, laser therapy, embolization and surgical resection (9). The primary goals of treating VM include alleviating pain, mitigation of functional disability and amelioration of cosmetic deformity (10). Severe VMs often persist despite current treatment alternatives (11), and for this reason, a novel therapeutic strategy utilizing rapamycin to alleviate VM was explored in the present study.

Rapamycin, as a macrolide antibiotic, allosterically regulates the process of substrates entering the catalytic site of the mammalian target of rapamycin (mTOR) (12). Rapamycin not only binds to mTOR but also serves as the prototypical inhibitor of mTOR (13). Produced by Streptomyces hygroscopicus, rapamycin has multiple biological and pharmacological properties (14), including immunosuppressive (15), anti-neoplastic (16), neuro-protective (17) and anti-aging activities (18). Rapamycin serves a critical role in modulating endothelial cells by repressing mTOR, and it can not only suppress inflammation, but also prevent and mitigate post-angioplasty coronary artery 
restenosis (19). Cell contact in endothelial cells is mediated by the characteristics of endothelial monolayers, regulating the biological behaviors of endothelial cells and contributing to vascular homeostasis (20). Accordingly, aberrant disruptions of cell contact in endothelial cells are of substantial importance in cardiovascular diseases and are key features of pathologically altered vascular endothelium (21). Venous endothelial cells have differing responses to angiogenic signals, thus the biological behaviors of endothelial cells have been investigated previously in the pathogenesis and treatment of VM (4). The aim of the current study was to investigate the effects of rapamycin on the biological behaviors of endothelial cells, such as proliferation, migration and apoptosis in human VMs.

\section{Materials and methods}

Cell separation and culture. Between January 2016 and January 2017, 10 cases of single oral buccal and facial VM were reported at Department of Oral and Maxillofacial Surgery, The Affiliated Stomatological Hospital of Nanjing Medical University, including 4 male and 6 female patients, with a mean age of $29.4 \pm 13.7$ years. The diagnosis of buccal facial vein malformation was confirmed by preoperative pathological examination. The inclusion criteria were as follows: Patients who were diagnosed with single oral buccal and facial venous malformation by pathological examination. The exclusion criteria were as follows: Patients who were diagnosed with other types of venous malformations on the face, hypertension, serious cardiovascular and cerebrovascular diseases, and other patients who were not suitable for treatment (for example cardiopulmonary dysfunction or poor recovery). The present study was approved by the Ethics Committee of The Affiliated Stomatological Hospital of Nanjing Medical University (Nanjing, China) and written informed consent was obtained from each subject. Surgically resected VM tissues were separated under aseptic conditions, and the exposed malformed vascular mass was cut open. Sponge-like sinusoids were then visualized and were sliced into tissue blocks of approximately $3-5 \mathrm{~mm}^{2}$. Following immersing in culture medium for minimal humidification, tissue blocks were inoculated in a culture flask that was subsequently plated on $1 \%$ gelatin, with the intima facing downward. Tissue blocks were separated by a distance of $\sim 5 \mathrm{~mm}$. The tissue blocks were then incubated in Dulbecco's modified Eagle's medium containing $20 \%$ fetal bovine serum (Gibco; Thermo Fisher Scientific, Inc., Waltham, MA, USA) at $37^{\circ} \mathrm{C}$ with the culture flask inverted. Following $6 \mathrm{~h}$, the culture flask was upended for incubation at $37^{\circ} \mathrm{C}$. Tissue blocks and non-adherent cells were removed, and adherent cells were incubation in Endothelial Cell medium (cat. no. 1001; ScienCell Research Laboratories, Inc., San Diego, CA, USA) for 3 days at $37^{\circ} \mathrm{C}$. Cellular morphology was observed under an inverted microscope at a magnification of $\mathrm{x} 400$, and cells outside the circle were removed using a cytopipette. Subsequently, tissue blocks were washed using PBS twice to remove other cells, and the culture medium was replaced. When cells had reached $70-90 \%$ confluency, $0.25 \%$ trypsin supplemented with ethylenediaminetetraacetic acid was used for cell subculture.

Identification of endovascular epithelial cells separated from deformed veins in human VM. Flow cytometry analysis was used to detect endovascular epithelial markers in order to identify endovascular epithelial cells. Separated cells from deformed veins in human VM were detached using $2.5 \mathrm{~g} / 1$ tryptase and centrifuged at $167 \mathrm{x} \mathrm{g}$ and $4^{\circ} \mathrm{C}$ for 5 min. The cells were washed with cold PBS at $4^{\circ} \mathrm{C}$ and centrifuged at $167 \mathrm{x} \mathrm{g}$ and $4^{\circ} \mathrm{C}$ for $5 \mathrm{~min}$. The washing and centrifugation were repeated and then the cells were made into a single cell suspension. With $1 \times 10^{6}$ cells per tube, a $15-\mathrm{min}$ incubation at $37^{\circ} \mathrm{C}$ was performed with the addition of $20 \mu \mathrm{l}$ phycoerythrin-conjugated anti-human cluster of differentiation (CD)31 antibody (cat. no. 566177; 1:500; BD Biosciences, San Jose, CA, USA), or a 30-min incubation at $4^{\circ} \mathrm{C}$ with the addition of $20 \mu \mathrm{l}$ mouse anti-human von Willebrand factor (vWF) monoclonal antibody (cat. no. 555849; 1:500; BD Biosciences). For determination of $\mathrm{CD} 31 / \mathrm{vWF}$, a simultaneous incubation was performed for $15 \mathrm{~min}$ at $37^{\circ} \mathrm{C}$. Subsequently, a second incubation for $30 \mathrm{~min}$ at $4^{\circ} \mathrm{C}$ with the addition of $50 \mu 1$ fluorescein isothiocyanate-labeled rabbit anti-mouse $\mathrm{IgG}$ (cat. no. TA130002; 1:1,000; OriGene Technologies, Inc., Beijing, China) was performed. Cells were place in tubes on the ice in the dark for $30 \mathrm{~min}$, washed three times using $2 \mathrm{ml}$ PBS and at $167 \times \mathrm{g}$ and $4^{\circ} \mathrm{C}$ and to remove the supernatant. Then $500 \mu \mathrm{l}$ PBS (containing $4 \%$ paraformaldehyde) was used to fix the cells at $4^{\circ} \mathrm{C}$ for $30 \mathrm{~min}$ prior to performing the flow cytometry. Cell identification was conducted using a FACSCan flow cytometer and the data was analyzed by Cell Quest Software (version 5.1; both BD Biosciences, Franklin Lakes, NJ, USA).

Cell grouping and treatment. The separated and determined endothelial cells of human VM were assigned into a blank group (cells cultured conventionally, without any treatment); a $1 \mathrm{ng} / \mathrm{ml}$ group (cells cultured in medium with rapamycin working solution at a concentration of $1 \mathrm{ng} / \mathrm{ml}$ ); a $10 \mathrm{ng} / \mathrm{ml}$ group (cells cultured in medium with rapamycin working solution at a concentration of $10 \mathrm{ng} / \mathrm{ml}$ ); a $100 \mathrm{ng} / \mathrm{ml}$ group (cells cultured in medium with rapamycin working solution at a concentration of $100 \mathrm{ng} / \mathrm{ml}$ ), and a 1,000 ng/ml group (cells cultured in medium with rapamycin working solution at a concentration of 1,000 ng/ml). Rapamycin was purchased from Hunan TaiRen Pharmaceutical Co., Ltd. (Changsha, China).

MTT assay. Cell viability of the endothelial cells in each group was measured at 24, 48 and $72 \mathrm{~h}$ following incubation. The optimal reaction time point for rapamycin was determined for the observation of cell morphological changes under an inverted microscope and other experiments. A cell suspension for each group was inoculated in 96-well plates at a density of $5 \times 10^{4}$ cells/well following dilution. A total of 6 reduplicate wells were set up for each group. Upon reaching $80 \%$ confluency, endothelial cells were treated as described above. Following reoxygenation, $20 \mu \mathrm{l}$ MTT solution (Sigma Aldrich; Merck KGaA, Darmstadt, Germany) was added and incubated for $4 \mathrm{~h}$ at $37^{\circ} \mathrm{C}$, followed by the removal of MTT solution. Subsequently, each well was supplemented with $150 \mu \mathrm{l}$ dimethyl sulfoxide (Sigma Aldrich; Merck $\mathrm{KGaA}$ ). Following shaking on a shaking table for $10 \mathrm{~min}$, the optical density (OD) value of each well was measured using a microplate reader at a wavelength of $490 \mathrm{~nm}$. The experiment was repeated 3 times, and the mean OD value 

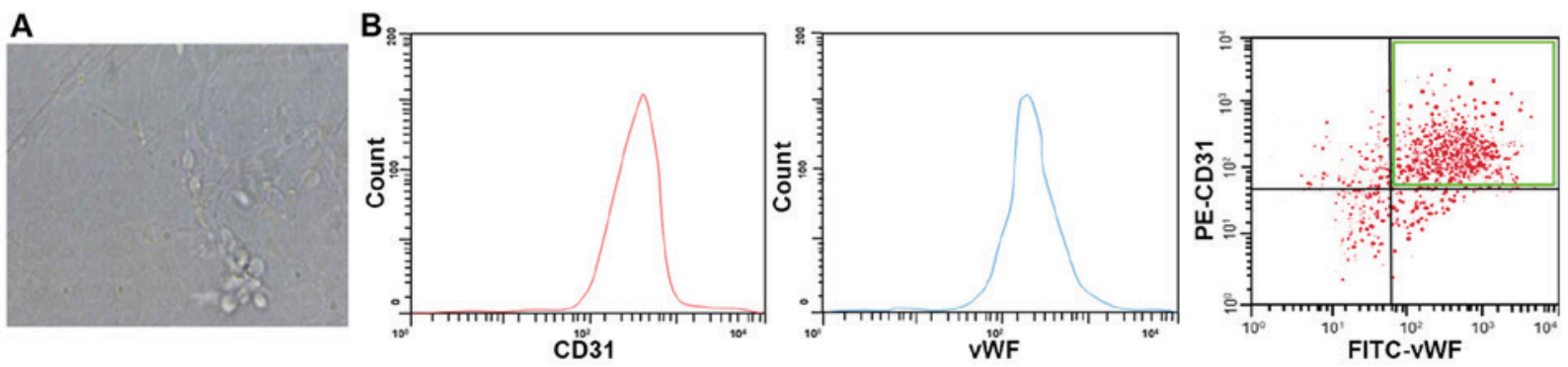

Figure 1. Cellular morphology of human venous malformation endothelial cells. (A) Observation of morphology of human venous malformation endothelial cells (original magnification, x200). (B) determination of the endovascular epithelial markers CD31, vWF, and CD31/vWF. CD, cluster of differentiation; vWF, von Willebrand factor; FITC, fluorescein isothiocyanate.

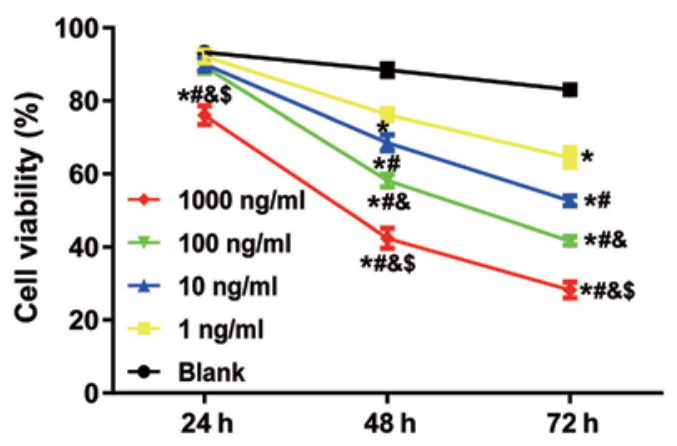

Figure 2. Comparison of the effects of rapamycin on the cell viability of human venous malformation endothelial cells at different concentrations and different time points. Comparisons among multiple groups were performed using two-way analysis of variance followed by a Tukey's post hoc test ${ }^{*} \mathrm{P}<0.05$ vs. blank; ${ }^{\#} \mathrm{P}<0.05$ vs. $1 \mathrm{ng} / \mathrm{ml}$ rapamycin; ${ }^{\&} \mathrm{P}<0.05$ vs. $10 \mathrm{ng} / \mathrm{ml}$ rapamycin; ${ }^{\$} \mathrm{P}<0.05 \mathrm{vs} .100 \mathrm{ng} / \mathrm{ml}$ rapamycin.

was calculated. Cell viability was calculated as follows: (OD value experimental group $-\mathrm{OD}$ value blank group $) / \mathrm{OD}$ value blank group .

Terminal deoxynucleotidyl-transferase-mediated dUTP nick end labelling (TUNEL) assay. Slides with attached cells were fixed in $4 \%$ (w/v) paraformaldehyde for $30 \mathrm{~min}$ at room temperature, rinsed in $\mathrm{PBS}$, blocked with $0.3 \% \mathrm{H}_{2} \mathrm{O}_{2}$ in methanol for $15 \mathrm{~min}$ at room temperature, and finally rinsed in PBS. Subsequently, slides were maintained in $0.1 \%$ Triton $\mathrm{X}-100$ at $4^{\circ} \mathrm{C}$ for $20 \mathrm{~min}$. The TUNEL assay (cat. no. C1098; Beyotime Institute of Biotechnology, Haimen, China) was performed according to the manufacturer's instructions. Slides were blocked with $3 \%$ bovine serum albumin (cat. no. C0225; Beyotime Institute of Biotechnology) at $37^{\circ} \mathrm{C}$ for $20 \mathrm{~min}$, followed by 3 washes with PBS ( 5 min per wash). Subsequently, peroxidase solution was added, and the slides were incubated in a humidity chamber at $37^{\circ} \mathrm{C}$ for $30 \mathrm{~min}$, followed by PBS washing 3 times ( $5 \mathrm{~min} /$ wash). Diaminobenzidine $(0.3 \mathrm{ml})$ as a substrate was added as a chromogen, and the slides were incubated in a humidity chamber at $15-20^{\circ} \mathrm{C}$ for $10 \mathrm{~min}$, followed by 3 washes with PBS ( 5 min per wash). Counterstaining was performed conventionally with hematoxylin at $37^{\circ} \mathrm{C}$ for $10 \mathrm{sec}$. Subsequently, ethanol-hydrochloric acid was used for differentiation, and ammonia was used to color the cells blue. The cells were mounted with 4\% Paraformaldehyde Fix Solution (cat. no. P0099; Beyotime Institute of Biotechnology) and photographed. Normal endothelial cells were stained blue, and apoptotic cells were yellow and brown. Five fields of vision were randomly selected. The apoptosis rate for a fixed area was calculated (apoptosis rate=apoptotic cells/total cells in a field).

Wound-healing assay. On the back of a 6-well plate, uniform horizontal lines at intervals of approximately $0.8 \mathrm{~cm}$ were drawn across the wells using a marker. Each well was crossed by at least 5 lines, and $\sim 5 \times 10^{5}$ cells were inserted into each well and grown to $100 \%$ confluency. The following day, a sterile $10-\mu 1$ pipette tip, perpendicular to the horizontal lines on the back, was used to scratch wounds along a ruler. Importantly, the pipette tip was upright, rather than slanted. Following wound scratching, the cells were rinsed gently with PBS 3 times. Then, PBS was added along the wall, and the scratched cells were rinsed and removed. The endothelial cells were incubated with culture medium in a $5 \% \mathrm{CO}_{2}$ incubator at $37^{\circ} \mathrm{C}$. Samples were taken at $48 \mathrm{~h}$ and then photographed. The rate of wound closure was calculated by measuring the distance between the two wound edges at $0 \mathrm{~h}$ and at $48 \mathrm{~h}$. The experiment was repeated 3 times, and the mean value was calculated.

Statistical analysis. SPSS 21.0 software (IBM Corp., Armonk, NY, USA) was used to analyze data in the present study. Measurement data are presented as the mean \pm standard deviation. Comparisons among multiple groups were performed using one-way or two-way analysis of variance followed by Tukey's post hoc test. $\mathrm{P}<0.05$ was considered to indicate a statistically significant difference.

\section{Results}

Observation and determination of human VM endothelial cells. The cellular morphology of separated human VM endothelial cells was observed under an inverted microscope. When the separated endothelial cells grew adherent to the wall, they were enlarged to different degrees and grew in clusters, resembling paving stones, with clear, homogeneous cytoplasm and a round or oval nucleus (Fig. 1A). For accurate identification of endovascular epithelial cells separated from the deformed vein of a human VM, flow cytometry was performed to evaluate a more specific marker for endovascular epithelial cells, CD31 and $\mathrm{vWF}$, and it was demonstrated that there were $92.5 \%$ CD31-positive cells, 88.2\% vWF-positive cells, and $76.3 \%$ CD31- and vWF-positive cells (Fig. 1B). 


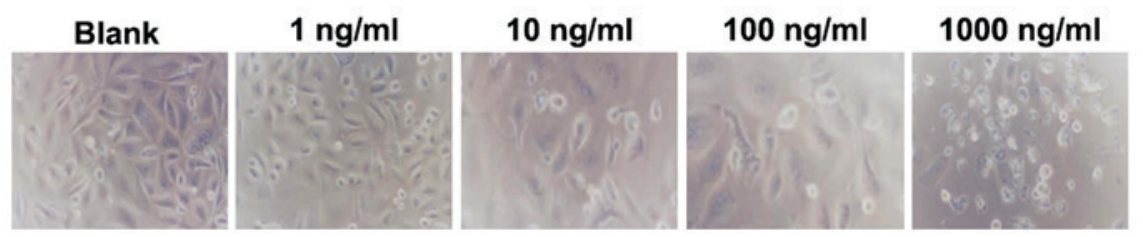

Figure 3. Comparison of the effects of rapamycin on cellular morphology of human venous malformation endothelial cells at different concentrations. Cellular morphology of human venous malformation endothelial cells treatment with increasing concentrations of rapamycin (original magnification, $\mathrm{x} 400$ ).

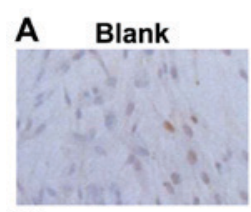

B
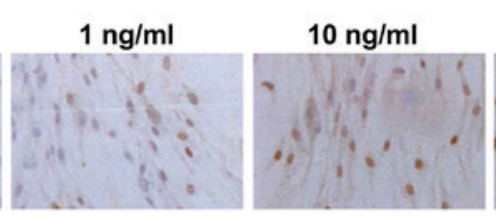

$100 \mathrm{ng} / \mathrm{ml}$

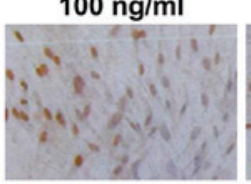

$1000 \mathrm{ng} / \mathrm{ml}$

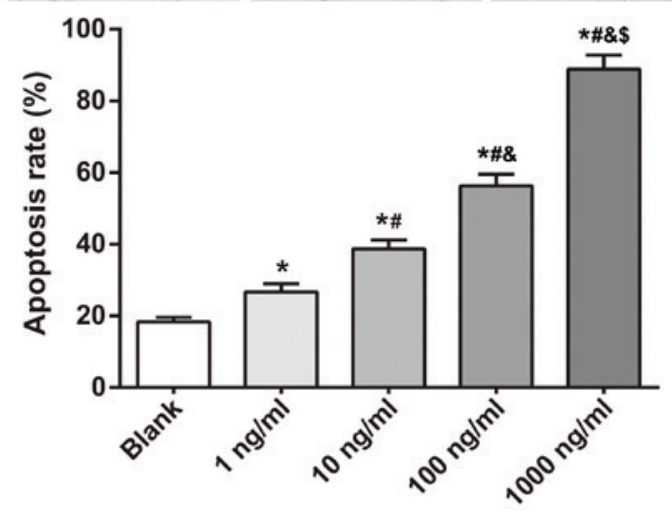

Figure 4. Comparison of the effects of rapamycin on cell apoptosis of human venous malformation endothelial cells at different concentrations. (A) Terminal deoxynucleotidyl-transferase-mediated dUTP nick end labeling staining to evaluate cell apoptosis (original magnification, x400). (B) The apoptosis rate of cells among different groups. Comparisons among multiple groups were performed using one-way analysis of variance followed by a Tukey's post hoc test. ${ }^{*} \mathrm{P}<0.05$ vs. blank; ${ }^{\mathrm{P}} \mathrm{P}<0.05$ vs. $1 \mathrm{ng} / \mathrm{ml}$ rapamycin; ${ }^{\circledR} \mathrm{P}<0.05$ vs. $10 \mathrm{ng} / \mathrm{ml}$ rapamycin; ${ }^{\$} \mathrm{P}<0.05$ vs. $100 \mathrm{ng} / \mathrm{ml}$ rapamycin.

Rapamycin inhibited the cell viability of human VM endothelial cells. An MTT assay was performed to detect the cell viability of human VM endothelial cells exposed to rapamycin (Fig. 2). Rapamycin significantly inhibited the proliferation of human VM endothelial cells at 48 and $72 \mathrm{~h}$. Higher concentration of rapamycin induced greater inhibitory effects. However, only rapamycin at a concentration of $1,000 \mathrm{ng} / \mathrm{ml}$ significantly inhibited the viability of human VM endothelial cells at $24 \mathrm{~h}$, suggesting that the inhibitory effects of rapamycin on human VM endothelial cells were concentration- and time-dependent. Therefore, $48 \mathrm{~h}$ following incubation was determined to be the optimal reaction time.

Effects of rapamycin on cellular morphology of human VM endothelial cells. An inverted microscope was used to observe the morphological changes of human VM endothelial cells exposed to rapamycin at different concentrations (Fig. 3). At $48 \mathrm{~h}$, when compared with the blank group, treatment with rapamycin at a concentration of $1 \mathrm{ng} / \mathrm{ml}$ produced a few shrunken cells and a reduced cell number; however, the majority of cells exhibited a clear boundary and a regular shape. Treatment with rapamycin at 10 and $100 \mathrm{ng} / \mathrm{ml}$ reduced the number of cells even further and caused some cells to become round and desquamated; treatment with rapamycin at $1,000 \mathrm{ng} / \mathrm{ml}$ produced more obvious desquamation, round-shaped cells and necrosis.
Rapamycin enhanced apoptosis conditions in human VM endothelial cells. A TUNEL assay was conducted to determine the apoptosis conditions of human VM endothelial cells exposed to rapamycin at different concentrations (Fig. 4). In comparison with the blank group, apoptosis of human VM endothelial cells was significantly elevated when treated with rapamycin at 1,10, 100 and 1,000 $\mathrm{ng} / \mathrm{ml}$. Higher concentrations yielded greater numbers of apoptotic endothelial cells, indicating that rapamycin treatment promoted the apoptosis of human VM endothelial cells.

Rapamycin inhibited the migration capacity of human VM endothelial cells. A wound-healing assay further verified the inhibitory effects of rapamycin on the migration capacity of human VM endothelial cells (Fig. 5). Compared with the blank group, rapamycin significantly suppressed the migration capacity of human VM endothelial cells at different concentrations. Higher concentrations yielded greater inhibitory effects.

\section{Discussion}

VMs damage the appearance and circulatory functioning of patients and even produce deadly bleeding and respiratory obstruction (3). Extensive VMs require lifelong treatment and may persist or become exacerbated $(7,22)$. Rapamycin has already been reported in clinical trials to serve as an effective treatment for cancer, vascular restenosis and immune rejection 


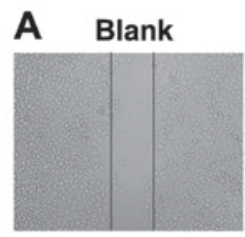

B
$1 \mathrm{ng} / \mathrm{ml}$
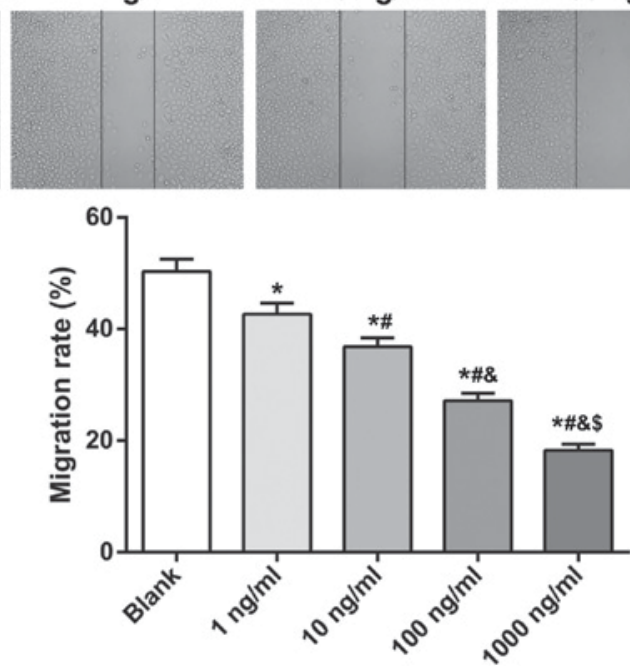

$10 \mathrm{ng} / \mathrm{ml}$
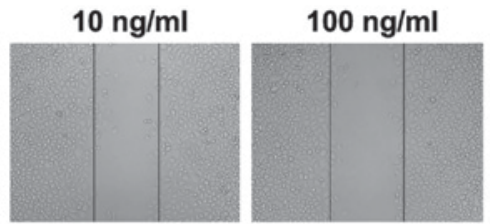

$1000 \mathrm{ng} / \mathrm{ml}$

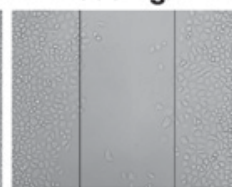
tion ability of cells detected by wound-healing assay (original magnification, x200). (B) Migration rate of cells among different groups. Comparisons among multiple groups were performed using one-way analysis of variance followed by a Tukey's post hoc test. " $\mathrm{P}<0.05 \mathrm{vs}$. blank; ${ }^{\prime} \mathrm{P}<0.05 \mathrm{vs}$. $1 \mathrm{ng} / \mathrm{ml} \mathrm{rapamycin}$; ${ }^{\&} \mathrm{P}<0.05$ vs. $10 \mathrm{ng} / \mathrm{ml}$ rapamycin; ${ }^{\$} \mathrm{P}<0.05$ vs. $100 \mathrm{ng} / \mathrm{ml}$ rapamycin.

of transplanted organs $(23,24)$. The aim of the present study was to explore the biological behaviors of human VM endothelial cells and their responses to rapamycin, which may be significant in the design of effective strategies for human VM treatment.

Initially, endothelial cells of human VM were separated and identified by detecting the positive expression of CD31 and vWF. CD31 and vWF are widely acknowledged as a specific marker for human endothelial cells (25); therefore, the strong positive expression of these markers confirmed the successful isolation of human VM endothelial cells. Endothelial cells secrete cytokines and adhesion molecules during the process of inflammation; additionally, accumulation of neutrophils within vascular endothelia is associated with the inflammatory process (2). Endothelial cells are also considered to be markers of endothelial dysfunction and endothelial injury (26). The number of proliferating endothelial cells and vascular SMCs is rather limited in normal vascular tissues, whereas a physiological or pathological stimulus can stimulate endothelial cells and SMCs to progress in the cell cycle (27). More specifically, it has been noted in a previous study that endothelial cells separated from VMs best represent the biological characteristics of VMs (4).

The cell viability of endothelial cells treated with rapamycin was determined by $\mathrm{MTT}$ assay at 24, 48 and $72 \mathrm{~h}$ following culture. The results indicated that rapamycin suppressed proliferation of human VM endothelial cells. As an mTOR inhibitor, rapamycin has been hypothesized to block the progression of cell cycle from $\mathrm{G}_{1}$ phase to $\mathrm{S}$ phase by inhibiting p70 ribosomal protein S6 kinase (p70S6K) $(13,28)$. mTOR, as a threonine kinase, phosphorylates S6K1 and 4E-BP1, and promotes transcription of key mRNAs associated with the progression of the cell cycle from $G_{1}$ phase to $S$ phase $(29,30)$. Through its interaction with p70S6K, it is associated with cell growth, proliferation and differentiation by regulating ribosome biogenesis, protein synthesis, cell cycle progression and metabolism (31). Consistent study demonstrates that rapamycin significantly represses the proliferation and migration of hemangioma, and reduces vascular tumor growth by suppressing the mTOR complex, which regulates cell mass and cell number. In addition, it has been revealed that rapamycin delays the aging process of mice by attenuating the degeneration of the liver and the heart, reducing the proliferation of adrenal gland lesions and altering tendon elasticity (32). Via its anti-proliferative properties, rapamycin reduces the cell viability of lymphocytes, vascular endothelial cells and SMCs and decreases the fibro-proliferative responses in vascular injuries (33).

The migration capacity of human VM endothelial cells was demonstrated to be suppressed following treatment with rapamycin. At the same time, apoptosis conditions in human VM endothelial cells were enhanced, as detected using flow cytometry. These findings are corroborated by the results of Liu et al (34), which demonstrated that rapamycin suppressed reendothelialization by attenuating the migration and promoting the apoptosis of endothelial cells following percutaneous coronary intervention. Inhibition of mTOR by rapamycin, has been revealed to repress the activity of vascular endothelial cell growth factor (VEGF) by inhibiting VEGF signal transduction and synthesis (35). Notably, VEGF is a crucial modulator for endothelial cell migration and angiogenesis (36). Barilli et al (37) demonstrated that rapamycin could damage cell viability and reduce migration of human endothelial cells through inhibition of mTOR complex 2 (mTORC2). A previous study by Zhu et al (38) indicated that rapamycin inhibits proliferation and migration of human vascular SMCs, preventing arteriovenous grafts in hemodialysis patients. The present study demonstrated that the effects of rapamycin on the biological behaviors of human VM endothelial cells were concentration- and time-dependent. Similarly, rapamycin has been demonstrated in an in vitro study to suppress the migration and promote the apoptosis of aortic endothelial cells in rats in a time- and dose-dependent manner (39). Rapamycin has been reported to decrease further expansion of VMs in mouse models, and ameliorate such symptoms and signs as 
pain, lesion size, bleeding and functional impairment in patients with VMs (40).

Altogether, evidence has been provided in this current study to suggest that rapamycin inhibits the proliferation and migration of human VM endothelial cells and accelerates their apoptosis. Furthermore, the effects of rapamycin exerted on human VM endothelial cells were concentration-dependent. However, the use of rapamycin may have adverse effects; therefore, further studies are required to investigate the safety and risk factors presented by the use of rapamycin in the treatment of VM.

\section{Acknowledgements}

Not applicable.

\section{Funding}

No funding received.

\section{Availability of data and materials}

The analyzed data sets generated during the study are available from the corresponding author on reasonable request.

\section{Authors' contributions}

HJ and YS conceived of the study, designed the study, and wrote and reviewed the manuscript. YS designed the study. HC, RX and WZ acquired the data. TX, XS and YF analyzed and interpreted the data. HJ supervised the study.

\section{Ethics approval and consent to participate}

This study was approved by the Ethics Committee of Affiliated Stomatological Hospital of Nanjing Medical University and written informed consent was obtained from each subject.

\section{Patient consent for publication}

Written informed consent was obtained from each subject.

\section{Competing interests}

The authors declare that they have no competing interests.

\section{References}

1. Boscolo E, Limaye N, Huang L, Kang KT, Soblet J, Uebelhoer M, Mendola A, Natynki M, Seront E, Dupont S, et al: Rapamycin improves TIE2-mutated venous malformation in murine model and human subjects. J Clin Invest 125: 3491-3504, 2015.

2. Jia Y, Jia J and Zhao Y: Pingyangmycin-regulated expressions of adhesion molecules in human venous malformation endothelial cells. J Huazhong Univ Sci Technolog Med 32: 760-766, 2012.

3. Zheng JW, Mai HM, Zhang L, Wang YA, Fan XD, Su LX, Qin ZP, Yang YW, Jiang YH, Zhao YF and Suen JY: Guidelines for the treatment of head and neck venous malformations. Int J Clin Exp Med 6: 377-389, 2013.

4. Wang Y, Qi F and Gu J: Endothelial cell culture of intramuscular venous malformation and its invasive behavior related to matrix metalloproteinase-9. Plast Reconstr Surg 123: 1419-1430, 2009

5. Buckmiller LM, Richter GT and Suen JY: Diagnosis and management of hemangiomas and vascular malformations of the head and neck. Oral Dis 16: 405-418, 2010.
6. Legiehn GM and Heran MK: Venous malformations: Classification, development, diagnosis, and interventional radiologic management. Radiol Clin North Am 46: 545-597, vi, 2008.

7. McRae MY, Adams S, Pereira J, Parsi K and Wargon O: Venous malformations: Clinical course and management of vascular birthmark clinic cases. Australas J Dermatol 54: 22-30, 2013.

8. Dompmartin A, Vikkula M and Boon LM: Venous malformation: Update on aetiopathogenesis, diagnosis and management. Phlebology 25: 224-235, 2010.

9. Lackner H, Karastaneva A, Schwinger W, Benesch M, Sovinz P, Seidel M, Sperl D, Lanz S, Haxhija E, Reiterer F, et al: Sirolimus for the treatment of children with various complicated vascular anomalies. Eur J Pediatr 174: 1579-1584, 2015.

10. Glade RS, Richter GT, James CA, Suen JY and Buckmiller LM: Diagnosis and management of pediatric cervicofacial venous malformations: Retrospective review from a vascular anomalies center. Laryngoscope 120: 229-235, 2010.

11. Lee AB, Laredo J and Neville R: Embryological background of truncular venous malformation in the extracranial venous pathways as the cause of chronic cerebro spinal venous insufficiency. Int Angiol 29: 95-108, 2010.

12. Malagelada C, Jin ZH, Jackson-Lewis V, Przedborski S and Greene LA: Rapamycin protects against neuron death in in vitro and in vivo models of Parkinson's disease. The J Neurosci 30: 1166-1175, 2010.

13. Shafer A, Zhou C, Gehrig PA, Boggess JF and Bae-Jump VL: Rapamycin potentiates the effects of paclitaxel in endometrial cancer cells through inhibition of cell proliferation and induction of apoptosis. Int J Cancer 126: 1144-1154, 2010.

14. Zhao S, Huang D, Qi H, Wen J and Jia X: Comparative metabolic profiling-based improvement of rapamycin production by Streptomyces hygroscopicus. Appl Microbiol Biotechnol 97: 5329-5341, 2013.

15. Huber TB, Walz G and Kuehn EW: mTOR and rapamycin in the kidney: Signaling and therapeutic implications beyond immunosuppression. Kidney Int 79: 502-511, 2011.

16. Nichols LA, Adang LA and Kedes DH: Rapamycin blocks production of KSHV/HHV8: Insights into the anti-tumor activity of an immunosuppressant drug. PLoS One 6: e14535, 2011.

17. Su W, Li Z, Jia Y and Zhuo Y: Rapamycin is neuroprotective in a rat chronic hypertensive glaucoma model. PLoS One 9: e99719, 2014.

18. Lamming DW, Ye L, Katajisto P, Goncalves MD, Saitoh M, Stevens DM, Davis JG, Salmon AB, Richardson A, Ahima RS, et al: Rapamycin-induced insulin resistance is mediated by mTORC2 loss and uncoupled from longevity. Science 335: 1638-1643, 2012.

19. Zheng N, Ding X and Jahan R: Low concentration of rapamycin inhibits hemangioma endothelial cell proliferation, migration, and vascular tumor formation in mice. Curr Ther Res Clin Exp 76: 99-103, 2014.

20. Wallez Y and Huber P: Endothelial adherens and tight junctions in vascular homeostasis, inflammation and angiogenesis. Biochim Biophys Acta 1778: 794-809, 2008.

21. DiStefano PV, Kuebel JM, Sarelius IH and Glading AJ: KRIT1 protein depletion modifies endothelial cell behavior via increased vascular endothelial growth factor (VEGF) signaling. J Biol Chem 289: 33054-33065, 2014.

22. Richter GT and Friedman AB: Hemangiomas and vascular malformations: Current theory and management. Int J Pediatr 2012: 645678, 2012.

23. Sarbassov DD, Ali SM, Sengupta S, Sheen JH, Hsu PP, Bagley AF, Markhard AL and Sabatini DM: Prolonged rapamycin treatment inhibits mTORC2 assembly and Akt/PKB. Mol Cell 22: 159-168, 2006.

24. Guba M, von Breitenbuch P, Steinbauer M, Koehl G, Flegel S, Hornung M, Bruns CJ, Zuelke C, Farkas S, Anthuber M, et al: Rapamycin inhibits primary and metastatic tumor growth by antiangiogenesis: Involvement of vascular endothelial growth factor. Nat Med 8: 128-135, 2002.

25. Gluhovschi C, Gluhovschi G, Potencz E, Herman D, Trandafirescu V, Petrica L, Velciov S, Bozdog G, Bob F, Vernic C and Cioca D: The endothelial cell markers von Willebrand factor (vWF), CD31 and CD34 are lost in glomerulonephritis and no longer correlate with the morphological indices of glomerular sclerosis, interstitial fibrosis, activity and chronicity. Folia Histochem Cytobiol 48: 230-236, 2010.

26. Mohamed AS, Thomson J, McDonald KJ, Hillyard DZ, Mark PB, Elliott HL and Jardine AG: Circulating endothelial cells in renal transplant recipients. Transpl Proc 37: 2387-2390, 2005. 
27. Humar R, Kiefer FN, Berns H, Resink TJ and Battegay EJ Hypoxia enhances vascular cell proliferation and angiogenesis in vitro via rapamycin (mTOR)-dependent signaling. FASEB J 16: 771-780, 2002.

28. Marqués L, Núñez-Córdoba JM, Aguado L, Pretel M, Boixeda P, Nagore E, Baselga E and Redondo P: Topical rapamycin combined with pulsed dye laser in the treatment of capillary vascular malformations in Sturge-Weber syndrome: Phase II randomized, double-blind, intraindividual placebo-controlled clinical trial. J Am Acad Dermatol 72: 151-158.e1, 2015.

29. Zhou C, Gehrig PA, Whang YE and Boggess JF: Rapamycin inhibits telomerase activity by decreasing the hTERT mRNA level in endometrial cancer cells. Mol Cancer Ther 2: 789-795, 2003

30. Nadal M, Giraudeau B, Tavernier E, Jonville-Bera AP, Lorette G and Maruani A: Efficacy and safety of mammalian target of rapamycin inhibitors in vascular anomalies: A systematic review. Acta Derm Venereol 96: 448-452, 2016.

31. Shin S, Wolgamott L, Yu Y, Blenis J and Yoon SO: Glycogen synthase kinase (GSK)-3 promotes p70 ribosomal protein S6 kinase (p70S6K) activity and cell proliferation. Proc Natl Acad Sci USA 108: E1204-E1213, 2011.

32. Wilkinson JE, Burmeister L, Brooks SV, Chan CC, Friedline S, Harrison DE, Hejtmancik JF, Nadon N, Strong R, Wood LK, et al: Rapamycin slows aging in mice. Aging Cell 11: 675-682, 2012.

33. Visner GA, Lu F, Zhou H, Liu J, Kazemfar K and Agarwal A: Rapamycin induces heme oxygenase-1 in human pulmonary vascular cells: Implications in the antiproliferative response to rapamycin. Circulation 107: 911-916, 2003

34. Liu HT, Li F, Wang WY, Li XJ, Liu YM, Wang RA, Guo WY and Wang HC: Rapamycin inhibits re-endothelialization after percutaneous coronary intervention by impeding the proliferation and migration of endothelial cells and inducing apoptosis of endothelial progenitor cells. Tex Heart Inst J 37: 194-201, 2010.
35. Moss SC, Lightell DJ Jr, Marx SO, Marks AR and Woods TC: Rapamycin regulates endothelial cell migration through regulation of the cyclin-dependent kinase inhibitor p27Kip1. J Biol Chem 285: 11991-11997, 2010.

36. Shirazi F, Cohen C, Fried L and Arbiser JL: Mammalian target of rapamycin (mTOR) is activated in cutaneous vascular malformations in vivo. Lymphat Res Biol 5: 233-236, 2007.

37. Barilli A, Visigalli R, Sala R, Gazzola GC, Parolari A, Tremoli E, Bonomini S, Simon A, Closs EI, Dall'Asta V and Bussolati O In human endothelial cells rapamycin causes mTORC2 inhibition and impairs cell viability and function. Cardiovasc Res 78: 563-571, 2008

38. Zhu W, Masaki T, Cheung AK and Kern SE: In-vitro release of rapamycin from a thermosensitive polymer for the inhibition of vascular smooth muscle cell proliferation. J Bioequiv Availab 1: 3-12, 2009.

39. Guo N, Chen F, Zhou J, Fang Y, Li H, Luo Y and Zhang Y: Curcumin attenuates rapamycin-induced cell injury of vascular endothelial cells. J Cardiovasc Pharmacol 66: 338-346, 2015.

40. Laurian C, Diner P, Enjolras O, LeMarchand-Venencie F, Herbreteau D and Merland JJ: Surgical treatment of superficial vascular malformations. Indications for tissue expansion. J Des Maladies Vasculaires 21: 31-35, 1996 (In French).

This work is licensed under a Creative Commons Attribution-NonCommercial-NoDerivatives 4.0 International (CC BY-NC-ND 4.0) License. 